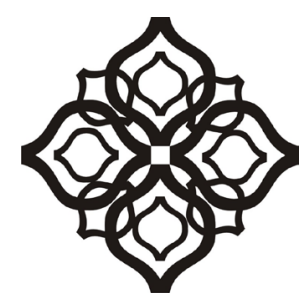

Shirkah

Journal of Economics and Business 


\section{Shirkah}

Journal of Economics and Business

Vol. 4, No. 1, January-April 2019

ISSN: 2503-4235 (p); 2503-4243 (e)

\section{Editor in Chief}

Fitri Wulandari

\section{Managing Editor}

Jasanta Peranginangin

\section{Editorial Boards}

Abdul Azim Islahi, Islamic Economics Institute, King Abdulaziz University, Saudi Arabia Abu Umar Faruq Ahmad, UBD School of Business and Economics Universiti, Brunei Darussalam Cedomir Nestorovic, ESSEC Business School Asia Pacific, Singapore

Fitri Wulandari, Faculty of Islamic Economics and Business, IAIN Surakarta, Indonesia Johan Fischer,

Department of Social Sciences and Business Roskilde Universitetscenter, Denmark Muhamed Zulkhibri, Islamic Research and Training Institute, Islamic Development Bank, Saudi Arabia M. Kabir Hassan,

Department of Economics and Finance, University of New Orleans, United States Musa Asy'arie,

Faculty of Islamic Economics and Business, IAIN Surakarta, Indonesia Nunung Nurul Hidayah, Aston Business School, Aston University, Birmingham, United Kingdom Saim Kayadibi,

Department of Economics, Kulliyyah of Economics and Management Science, International Islamic University Malaysia, Malaysia 
Shaikh M Ghazanfar,

Departement of Economics, University of Idaho, Russian Federation

Sigit S. Wibowo,

Department of Management, Faculty of Economics and Business, Universitas Indonesia, Indonesia

Vihang R. Errunza,

Desmarais Global Finance Research Centre, Desautels Faculty and Management, McGill University, Canada

\section{Assistant to Editor \\ M. Endy Saputro \\ M. Zainal Anwar}

Shirkah Journal of Economics and Business is a peer-reviewed journal published three times a year (January-April, May-August and September-December) by Faculty of Islamic Economics and Business, Institut Agama Islam Negeri (IAIN) Surakarta Central Java, Indonesia. The main objective of Shirkah is to offer an academic space of exchange ideas and initiate the increase number of qualified article produced by postgraduate students, practitioners and academicians.

\section{Editorial Office}

Ruang Jurnal Shirkah

Lantai Dasar, Sayap Barat, Fakultas Ekonomi dan Bisnis Islam, IAIN Surakarta

Jln. Pandawa No. 1, Kartasura, Sukoharjo, Jawa Tengah Kode Pos. 57168

Phone (+62271) 781516 Fax: (+62271)782336

E-mail: shirkahjournal@iainsurakarta.ac.id; shirkahiainsurakarta@gmail.com

Website: http://shirkah.or.id/ 


\section{Shirkah}

Journal of Economics and Business

Vol. 4, No. 1, January-April 2019

ISSN: 2503-4235 (p); 2503-4243 (e)

\section{Table of Contents}

\section{Articles}

Datien Eriska Utami

Identifying Financial and Non-Financial Factors as

the Determinant of Sukuk Rating in Indonesia

JM Muslimin

Halal Product Guarantee in

Indonesia Regulation and Social Inclusion

Isnan Indriati

Muh. Rudi Nugroho

Kuznet's Hypothesis and Ibn Khaldun's Socio-Economic Dimensions

Lucky Nugroho

Ahmad Badawi

Nurul Hidayah

Indonesia Islamic Bank Profitability 2010-2017

Aam Slamet Rusydiana

Lina Marlina

Lina Nugraha Rani

Malmquist Productivity Index on Islamic Economics and

Finance Research

Ahmad Farras Adibuddin

Doddy Setiawan

Bambang Sutopo

The Recent Development of Islamic Economic Studies in Indonesia 


\title{
Identifying Financial and Non-Financial Factors as the Determinant of Sukuk Rating in Indonesia
}

\author{
Datien Eriska Utami \\ Sharia Business Management, Faculty of Islamic Economics and Business, \\ IAIN Surakarta \\ datieneriska@yahoo.co.id
}

\begin{abstract}
The present study aims to identify financial and non-financial factors as the determinant variables of Indonesian companies' Sukuk ratings between 2014 and 2017. Five independent variables, i.e. firm size, profitability, leverage, guarantee status, and types of Sukuk, are involved in this study with Sukuk rating as the dependent variable. This study employed secondary data in the form of sixty-eight (68) Sukuk publications as the sample. The Sukuk publications observed in this study were still in circulation during the observation years obtained from Otoritas Jasa Keuangan (OJK/ Financial Services Authority) websites, annual reports of companies listed in Indonesia Stock Exchange, and PT Pefindo website. By utilizing Multinomial Logistic Regression, this study reveals that the financial factor, the profitability, had a significant effect on the Sukuk rating. Moreover, it also shows that the non-financial factor influencing the Sukuk rating was the guarantee status. On the contrary, the variables of firm size, leverage, and types of Sukuk did not affect the Sukuk rating.
\end{abstract}

Keywords: firm size, profitability, leverage, guarantee status, types of Sukuk, Sukuk rating

\section{Introduction}

A Sukuk is an financial certificate that complies with Islamic religious law commonly known as sharia. According to the Accounting and Auditing Organization for Islamic Financial Institutions (AAOFI), Sukuk is a certificate of equal value which functions as ownership evidence of assets and services of a certain investment project. In Indonesia, the Sukuk 
market has been rapidly growing for recent decades. Based on the report established by the Financial Service Authority in 2018, the number of Sukuk publications reached 137 items or equal to IDR 26.394 .90 billion per December 2017. It has improved by $19.96 \%$ than the yesteryear.

The rapid growth of the Sukuk market as an alternative to the conventional bond market promotes the Sukuk rating become an important factor of Sukuk market development. The Sukuk rating has been utilized as a risk indicator of all Sukuk which are issued through the punctuality of principal payment and profit sharing (Elhaj, Muhamed, \& Ramli, 2015). Sukuk rating has been also needed by investors to understand the prospect and development of an established Sukuk and to predict risks and returns obtained from the investment. According to Borhan and Ahmad (2018), the issued Sukuk has annually been ranked to reveal their working performances.

Sukuk and Bond Rating Agency aims to provide information about the fit of an bond or Sukuk established by companies. Ahmed et al. (2014) state that the Sukuk and bond rating gives information about the legitimation of the issued Sukuk. Furthermore, Arundina, Azmi Omar, and Kartiwi (2015) add that the existence of the Sukuk and Bond Rating Agency will reduce information asymmetry about the established products that occur between the publisher and the investor. Moreover, Sukuk Rating Agencies in Indonesia which have been recognized by Bank Indonesia are Fitch Ratings, Moody's Investor Service, Standard and Poor's, PT Fitch Rating Indonesia, PT ICRA Indonesia, and PT Pemeringkat Efek Indonesia (Perfindo). Various methods and approaches have been utilized in the process of Sukuk and bond rating. Nevertheless, financial and nonfinancial are two factors that could be employed as assessment instruments in the process of Sukuk rating. 
The present study attempts to identify financial and non-financial fundamental factors that potentially affect the corporate Sukuk rating of a company. The theory of Modal Structure argues that several financial ratios have an impact on the company's capital, both equity and debt. A previous study conducted by Ngano $(2016,2017)$ confirms that the financial fundamental factors of the capital can be equalized with financial fundamental factors of corporate Sukuk publication. These financial fundamental factors include the level of leverage, profitability and firm size (Borhan \& Ahmad, 2018; Elhaj et al., 2015; Grassa, 2017; Hovakimian, Opler, \& Titman, 2001; Mohamed, Masih, \& Bacha, 2015). Leverage and profitability have been the fundamental basis of a company's finance showing the amount of profit in paying its long-term bond. It has been a common practice that the companys' assets are frequently considered as the standard of the operational activities (Martinus \& Suryaningsih, 2014). In doing so, the bigger the firm size, the greater the number of its operational activities that will contribute to the level of the Sukuk rating. In this case, Borhan and Ahmad (2018) indicate that the firm size which was represented by its total assets did not affect the Sukuk rating. However, on the contrary, the finding of studies conducted by Melani and Kananlua (2013) and Arundina (2019) reveal that the firm size significantly affected the Sukuk rating.

The non-financial factor which is related to corporate Sukuk publication employed in this study is the guarantee status of the Sukuk given by the publisher. The guaranteed Sukuk with high-value assets will enhance investors' trust toward the company. The company consistently fulfills the principal loan payment and the interest, its corporate Sukuk rating will continuously increase. Related to this, the finding revealed by Borhan and Ahmad (2018) and Arundina (2009) point out the significant effect between the guarantee status of Sukuk and the Sukuk rating. 
Another non-financial factor considered by this study is the types of Sukuk used by the company. In Indonesia, the frequently traded types of Sukuks are mudharaba and ijarah. Sukuk ijarah possesses lower risks rather than Sukuk mudharaba. Investors who choose Sukuk ijarah will obtain ujrah - a regular income, while those who take mudharaba will experience profit sharing. Ahmad (2018) and Abulgasem et al. (2015) state that the types of Sukuk has a positive effect on the Sukuk rating of a company. Studies on the models used to predict Sukuk rating have been statistically and qualitatively conducted for years. Multinomial Logistic Regression model, for instance, was utilized by Arundina, Azmi Omar, and Kartiwi (2015) to forecast a Sukuk rating of a Malaysian Sukuk publisher. Additionally, the Artificial Neutral Network model (ANN) was employed by Kumar and Bhattacharya (2006) to envisage the Sukuk rating based on the financial performance data of several Malaysian corporate Sukuk issuers.

The ability to identify some determinant factors that affect the Sukuk rating of a company will potentially decrease information asymmetry when investors are involved in a Sukuk transaction. Identifying a Sukuk rating is a process of assessing the principal payment probability and the interest within the determined period. The higher the Sukuk rating, the lower the risk (Elhaj et al., 2015). In this case, the Sukuk Rating Agency as the information intermediary to investors plays an important role in providing assessment toward the fit of the Sukuk publisher. In terms of the rating method, there is no methodological difference between corporate bond rating and corporate Sukuk rating since they have similar characteristics. This study purposes to examime the determinant factors of the Indonesian corporate Sukuk rating under analysis of agency theory. 


\section{Agency Theory and Information Asymmetry}

Jensen and Meckling (1976) state that conflict of interest often occurs between an investor and a company's manager that will influence an investment. The conflict of interest could also happen between the shareholder and the bondholder. In a company, a bondholder has a different interest with a shareholder (Borhan \& Ahmad, 2018). While the shareholder focuses on expanding investment, the bondholder perceives that a company should be managed carefully so that it can fulfill its bond. The agency theory can be used to measure the relation between the Sukuk owner (principal) and the company (agent) as the basic concept of the correlation between the Sukuk rating and the determinant variables (Borhan \& Ahmad, 2018). Jasen (1986) argues that debt triggers a manager to be more efficient so that the company will return its debt regularly. However, the agency theory also states that between the Sukuk owner and the company often possess different purposes, which result in a conflict of interest. In addition, according to the agency theory, the company with a high amount of profits is able to pay its bond punctually which situates the Sukuk rating increases.

The relation between the Sukuk publisher and the Sukuk holder can also be explained through asymmetry theory which states that in an inefficient market, an investor may have information access to the financial assets that will encourage the market price. Asymmetry information enables investors contributing negative judgment to companies. According to signaling theory, this is called polling equilibrium, which is categorizing good-quality companies and bad-quality companies in one pool. Goodquality companies have an incentive to convince investors. Some previous studies have mentioned that in order to avoid the information asymmetry, investors rely on the Sukuk rating established by rating agencies as the base of making a decision (Katz, 1974; Gup, 2005; Listokin, 2010). 


\section{Determinant Variables}

Independent variables used in this study as the determinant of Sukuk rating are profitability, leverage, firm size, guarantee status, and types of Sukuk. Profitability demonstrates the level of the company's ability in obtaining profits. In this study, the level of profitability is measured by Return on Asset (ROA). Borhan and Ahmad (2018) explain that the profitability ratio which has been measured by ROA significantly influenced the Sukuk rating. Elhaj et al (2015), in their research on Malaysian issued Sukuk rating, reveals that the variable of profitability positively correlated with the Sukuk rating. On the contrary, a study conducted by Arundina (2009) indicates a negative correlation between ROA and the Sukuk rating. Thus, the hypothesis (H1) formulated in this study is the level of profitability has a positive effect on the Sukuk rating.

Leverage indicates the level of companies' ability to fulfill their short-term and long-term bonds. This ratio also shows debt use proportion in the company operation. The higher the leverage ratio obtained describes the higher the risk faced by the company because the investors will demand more profits. The leverage ratio in this study is measured by Debt to Equity Ratio (DER) by dividing the total of debt with the total of assets. Such previous findings mention that the leverage ratio positively contributed to the Sukuk rating. Elhaj et al (2017) elucidate that leverage has a positive effect on the Sukuk rating. In a similar direction, a study by Azmat, Skully, and Brown (2017) reveal that the variable of leverage ratio significantly contributed to the growth of the Sukuk rating. Therefore, the formulation of the hypothesis (H2) is the level of leverage has a positive effect on the Sukuk rating.

Firm size is closely related to the number of assets held by the company which is used to fund its operational activities. As a result, the 
company's ability to earn profits will increase as well as it will decrease the default risk. Theoretically, a larger company has a greater certainty than a smaller company, so it will decrease the uncertainty of the company's prospect. Thus, the Sukuk issued by the company will potentially have a better level of rating. Therefore, the hypothesis (H3) formulated in this study is firm size has a positive effect on the Sukuk rating.

A guarantee is an asset promised for the creditor if someday the debtor cannot return the money. Meanwhile, the bond guarantee is a guarantee for the bondholder that the payment of interest will be carried out by the third party when liquidation happens (Borhan \& Ahmad, 2018). Sukuk and bond with a guarantee have lower risk rather than without guarantee. Moreover, a guaranteed Sukuk will potentially receive a better investment grade (Ma'arij et al., 2014). Furthermore, the Sukuk rating will grow continuously if the company's assets are guaranteed for the Sukuk. This is confirmed by the finding of research conducted by Borhan and Ahmad (2018) that reveal a positive correlation between the guarantee status of Sukuk and the Sukuk rating. Therefore, the hypothesis (H4) in this study is guarantee status of Sukuk has a positive effect on the Sukuk rating.

According to the report of the Financial Services Authority per 2017, the types of Sukuk issued by Indonesian companies are commonly ijarah and mudharaba. However, the type of ijarah dominates the Sukuk publications, since this type of Sukuk has a lower risk compared to Sukuk mudharaba. One of the advantages of Sukuk ijarah is the investors will obtain a sustainable income called ujrah, while if they choose Sukuk mudharaba, they will experience sharing of profits. Prior studies conducted by Borhan and Ahmad (2018) and Abulgasem et al. (2015) state that types of Sukuk influence the corporate Sukuk rating. Concerning market reaction, such studies also show that the establishment of Sukuk Ijarah by a 
company always results in a positive response from the market (Godlewski et al., 2014). It causes by the debt-based instrument which becomes the basis of Sukuk Ijarah establishment instead of Sukuk mudharaba that is based on the equity of profit sharing. Additionally, some other studies mention that debt-based Sukuk such as ijarah is considered as having a high value rather than Sukuk mudharaba because it is supported by assets that give a feeling of security to the investors (Yaakub et al., 2011). Thus, the formulation of the hypothesis (H5) is types of Sukuk have a positive effect on the Sukuk rating.

\section{Research Method}

The data of this study are the issued Sukuk obtained from the companies that are listed at Indonesia Stock Exchange and PT Perfindo between 2014 and 2017. The total population are 79 Sukuk publication until 2017. Purposive sampling method was employed by considering some criteria. First, Sukuk must had been issued during 2014 - 2017. Second, the issuer should have been the companies that established the complete financial reports as required in this study. As a result, 68 annual financial reports of the companies as Sukuk issuers matched the criteria. They were used as the sample of this study and could be accessed on the Indonesia Stock Exchange's website through idx.co.id. Moreover, the Sukuk that has been issued until 2017 was obtained from the Financial Services Authority's website at ojk.go.id. Furthermore, the data source of Sukuk rating was earned from PT Perfindo's website at perfindo.com

This study made use of Multinomial Logistic Regression to examine the effect of independent variables, i.e. profitability, leverage, firm size, guarantee status, and types of Sukuk, toward Sukuk rating as the dependent variable established by Indonesia Stock Exchange and ranked by PT Perfindo. Sukuk rating as the dependent variable is a nominal 
variable having six categories: idAAA(sy), idAA-(sy), idA+(sy), idA(sy), idA-(sy) and idBBB(sy). The reference category is idBBB(sy) and the Logit Multinominal Model will count the logit by using that reference.

The independent variables of this study are financial and nonfinancial as explained above, which are profitability, leverage, firm size, guarantee status, and types of sukuk. First, according to Arundina and Omar (2019), the variable of profitability can be measured by using Return On Assets (ROA). The ROA is counted by dividing the Earnings before Interest and Tax (EBIT) with the total company assets. Second, the variable of leverage is calculated by using Debt to Equity Ratio (DER) (Azmat et al., 2017). DER is determined by dividing the total amount of debt with total equity. Third, the variable of firm size is computed by using total assets (Borhan \& Ahmad, 2018) with the measurement of the natural log of the total assets in the data processing. Fourth, the guarantee status is a dummy variable, which means if the issued Sukuk is guaranteed, the value is 1 , but if it is not guaranteed, the value is 0 (Borhan $\&$ Ahmad, 2018). The last, types of sukuk in this study is also a dummy variable, which means if the issued Sukuk is ijarah, the value is 1 , but if it is mudharaba, the value is 0 (Borhan \& Ahmad, 2018).

\section{Multinominal Logistic Regression Model (M-Logit)}

The present study took into account Multinomial Logistic Regression (M-Logit) as the method of qualitative data analysis. The M-Logit strategy enables a category to assume a particular value. This category is used as the reference of other categories that is often called as base line. The M-Logit coefficient in base line logit model is commonly written as follow: 


$$
\log \frac{p(\text { groupj })}{p(\text { groupuJ })}=\alpha_{0}+\beta_{i 1} X_{1}+\beta_{i 2} X_{2}+\cdots+\beta_{i n} X_{n}
$$

Category $\mathrm{J}$ in the divider refers to the determined base line category, while category $\mathrm{j}$ in the numerator refers to a particular category in the variable.

$$
\begin{array}{ll}
\alpha_{0} & =\text { constant term } \\
\beta & =\text { respective coefficient of predictor } \mathrm{X} \\
X_{1} X_{1} & =\text { predictor variable (independent) }
\end{array}
$$

The common form of M-Logit model equation in this study which refers to the above equation is as follow:

$$
\begin{aligned}
& \log \frac{p(A A A)}{p(B B B)}=\beta_{0}+\beta_{1} P R F_{i, t}+\beta_{2} L E V_{i, t}+\beta_{3} F S_{i, t}+\beta_{4} G S_{i, t}+\beta_{5} S T_{i, t} \\
& \log \frac{p(A A-)}{p(B B B)}=\beta_{0}+\beta_{1} P R F_{i, t}+\beta_{2} L E V_{i, t}+\beta_{3} F S_{i, t}+\beta_{4} G S_{i, t}+\beta_{5} S T_{i, t} \\
& \log \frac{p(A+)}{p(B B B)}=\beta_{0}+\beta_{1} P R F_{i, t}+\beta_{2} L E V_{i, t}+\beta_{3} F S_{i, t}+\beta_{4} G S_{i, t}+\beta_{5} S T_{i, t} \\
& \log \frac{p(A)}{p(B B B)}=\beta_{0}+\beta_{1} P R F_{i, t}+\beta_{2} L E V_{i, t}+\beta_{3} F S_{i, t}+\beta_{4} G S_{i, t}+\beta_{5} S T_{i, t} \\
& \log \frac{p(A-)}{p(B B B)}=\beta_{0}+\beta_{1} P R F_{i, t}+\beta_{2} L E V_{i, t}+\beta_{3} F S_{i, t}+\beta_{4} G S_{i, t}+\beta_{5} S T_{i, t}
\end{aligned}
$$

Explanation: 


$$
\begin{array}{ll}
\frac{p(A A A)}{p(B B B)} & =\text { probability of getting AAA rather than } \mathrm{BBB} \\
\frac{p(A A-)}{p(B B B)} & =\text { probability of getting AA- rather than } \mathrm{BBB} \\
\log \frac{p(A+)}{p(B B B)} & =\text { probability of getting A+ rather than } \mathrm{BBB} \\
\log \frac{p(A)}{p(B B B)} & =\text { probability of getting A rather than } \mathrm{BBB} \\
\log \frac{p(A-)}{p(B B B)} & =\text { probability of getting A-rather than } \mathrm{BBB}
\end{array}
$$

\footnotetext{
$P R F_{i, t} \quad=$ profitability that is measured by using ROA

$L E V_{i, t} \quad=$ leveragethat is measured by using DER

$\mathrm{FS}_{\mathrm{i}, \mathrm{t}} \quad=$ firm size that is measured from total assets of natural log

$G S_{i, t} \quad=$ guarantee status that is measured by 1 for the guaranteed Sukuk and 0 for the non-guaranteed Sukuk.

$S T_{i, t} \quad=$ Sukuk Ijarah and Mudharabah that are measured by dummy variable in which 1 is for Sukuk Ijarah and 0 is for Sukuk Mudharabah.
}

\section{M-Logit Model Testing}

There have been several tests to examine the data before conducting Multinomial Logistic Regression test. An outlier test was employed to assess the raw data from the extreme data. It was conducted by considering the boxplot of each independent variable. The extreme outlier notified from the boxplot could be omitted (Borhan \& Ahmad, 2018). The regression model can be used if it has a normal data distribution. The data are assessed by using a normality test to see whether the regression model of independent and dependent variables have a normal distribution. The normality test is conducted by using the One-Sample Kolmogorov-Smirnov test. When the 
residual value reaches 0.05 , it is concluded that the residual has followed the normal distribution.

Collinearity test is used to determine whether a linear relation correlates positively or not with the independent variables. This test is conducted by employing Pearson Correlation Matrix in which the correlation among independent variables is considered as high if it reaches more than 0.8 (Borhan \& Ahmad, 2018).

\section{Hypothesis Testing}

The Multinomial Logistic Regression in hypothesis testing can be explained as follows. Model Fitting Information test is used to determine the fit or how effective the model employed. The information on model fit is measured through $-2 \log (-2 \log$ Likelihood). The model is considered as significant or matches with the data if $\mathrm{p}$-value $<0.05$ (Ghozali, 2013: 340). The Goodness of Fit test is conducted to provide information about whether the model used fits with the data (Ghozali, 2013: 340). This test is also used to check the parameter to define the model fit, which does not reject the null hypothesis model with p-value $>0.05$ or $5 \%$.

The Pseudo R-Square test functions to examine that the independent variables can explain the dependent variable. This test is conducted by using Cox and Snell R-Square test and Nagelkerke R-Square. The result will determine how much the percentage of the independent variable in explaining the dependent variable (Borhan \& Ahmad, 2018). This will present $\mathrm{R}^{2}$ value or determination coefficient. The value which closes to 1 shows that the independent variables are able to explain the variation of the dependent variable (Ghozali, 2013: 95).

The Likehood Ratio test is employed to find out the effect of each independent variable toward the dependent variable (Borhan \& Ahmad, 2018). According to Ghozali (2013: 341), the Likehood Ratio table 
explains the contribution of each independent variable to the model. The variable is considered as having contribution should have $\mathrm{p}$-value $<0.05$. The last, the regression analysis in this study is used to determine the effect of independent variables, i.e. firm size, profitability, leverage, guarantee status, and Types of Sukuk, toward Sukuk rating as the dependent variable.

\section{Result}

The population of this study is seventy-nine Sukuk issued by the companies listed at the Indonesian Stock Exchange from 2014-2017. By employing purposive sampling technique, seventeen Sukuk issued by eight companies were selected as the samples of this study, so that the total samples during the four-year observation were sixty-eight.

\section{Techniques of Data Testing}

The result of the classical assumption test in this study is as follows:

\section{Outlier Test}

Among the selected Sukuk as the samples of this study, there were some extreme outliers. Based on the boxplot data, it was found twelve extreme outliers from the independent variables, therefore, the samples remain fifty-six.

\section{Normality Test}

The normality test in this study is conducted by using One-Sample Kolmogorov-Smirnov. The result showed that the significant value or p-value $>0.05$, precisely 0.143 , which means the data are normal.

\section{Collinearity Test}

The collinearity test in this study is administered by using Pearson correlation analysis. Collinearity occurs if the correlation value among the independent variables is higher than 0.08 . Based on the Pearson correlation 
test, it was found that there was no significant correlation among the independent variables.

\section{Hypothesis Testing}

\section{Rating Class Distribution}

In this study, one sample of rating class is synthesized to build a model, to predict case, and to assess the significance of variables. The table below presents the rating class distribution of the Sukuk as the samples of this study.

Table 1. Rating Class Distribution

\begin{tabular}{llll}
\hline & & $\mathrm{N}$ & Marginal Percentage \\
\hline Y & idAAA(sy) & 30 & $53,6 \%$ \\
& idAA-(sy) & 1 & $1,8 \%$ \\
& idA+(sy) & 8 & $14,3 \%$ \\
& idA(sy) & 5 & $8,9 \%$ \\
& idA-(sy) & 6 & $10,7 \%$ \\
Valid & idBBB(sy) & 6 & $10,7 \%$ \\
Missing & & 56 & \\
Total & & 0 & \\
\hline
\end{tabular}

\section{Empirical Model}

The regression analysis utilized backward elimination method (Borhan \& Ahmad, 2018). From the five independent variables, there were no eliminated variables. 


$$
\begin{aligned}
\log p\left(\frac{A A A}{B B B}\right)= & -6971,567+308,881 F S+24961,923 P R F+679,863 L E V \\
& +52,708 G S-438,306 S T
\end{aligned}
$$

Equation 2, predicted logit AA-compared to BBB:

$$
\begin{aligned}
\log p\left(\frac{A A-}{B B B}\right)= & -8812,614+343,030 F S+50727,049 P R F-505,614 L E V \\
& +1529,221 G S+2387,467 S T
\end{aligned}
$$

Equation 3, predicted logit A+ compared to BBB:

$$
\begin{aligned}
\log p\left(\frac{A+}{B B B}\right)= & -208,283+26,110 F S-7253,438 P R F+148,475 L E- \\
& 420,492 G S-213,154 S T
\end{aligned}
$$

Equation 4, predicted logit A compared to BBB:

$$
\begin{aligned}
\log p\left(\frac{A}{B B B}\right)= & -8731,706+309,827 F S+58668,766 P R F-631,937 L E V \\
& +2159,804 G S+2600,981 S T
\end{aligned}
$$

Equation 5, predicted logit A-compared to BBB:

$$
\begin{aligned}
\log p\left(\frac{A-}{B B B}\right)= & 6225,007-275,768 F S-22258,298 P R F-607,465 L E V \\
& -48,124 G S+393,557 S T
\end{aligned}
$$

Table 2. Result of Backward Analysis

\begin{tabular}{llrrrrr}
\hline $\mathrm{Y}^{\mathrm{a}}$ & \multicolumn{1}{c}{$\mathrm{B}$} & Std. Error & Wald & df & Sig. \\
\hline idA-(sy) & Intercept & 6225,007 & 15090,726 &, 170 & 1 &, 680 \\
& CompanySize & $-275,768$ & 797,491 &, 120 & 1 &, 729 \\
& Profitability & $-22258,298$ &, 000 &. & 1 &. \\
& Leverage & $-607,465$ & 2089,401 &, 085 & 1 &, 771 \\
& GuaranteeStatus=0 & $-48,124$ & 3653,189 &, 000 & 1 &, 989 \\
& GuaranteeStatus=1 & $0^{c}$ & &. & 0 &. \\
& GuaranteeStatus=0 & 393,557 & 3229,074 &, 015 & 1 &, 903
\end{tabular}

Vol. 4 No. 1, January - April 2019 


\begin{tabular}{|c|c|c|c|c|c|c|}
\hline & GuaranteeStatus $=1$ & $0^{c}$ & • & . & 0 & \\
\hline \multirow[t]{8}{*}{ idA(sy) } & Intercept & $-8731,706$ & 89145,690 & 010 & 1 & ,922 \\
\hline & CompanySize & 309,827 & 4985,480 &, 004 & 1 & 950 \\
\hline & Profitability & 58668,766 & 311174,681 & ,036 & 1 &, 850 \\
\hline & Leverage & $-631,937$ & 2335,660 & 073 & 1 & ,787 \\
\hline & GuaranteeStatus $=0$ & 2149,804 & 24183,083 & ,008 & 1 & 929 \\
\hline & GuaranteeStatus $=1$ & $0^{c}$ & . & - & 0 & \\
\hline & GuaranteeStatus $=0$ & 2600,981 & 14815,643 & ,031 & 1 & ,861 \\
\hline & GuaranteeStatus $=1$ & $0^{c}$ & ${ }^{\circ}$ & . & 0 & . \\
\hline \multirow[t]{8}{*}{$\mathrm{idA}+($ sy) } & Intercept & $-208,283$ & 7069,753 & ,001 & 1 & 976 \\
\hline & CompanySize & 26,110 & 423,269 &, 004 & 1 & 951 \\
\hline & Profitability & $-7253,438$ & 55145,020 & ,017 & 1 & ,895 \\
\hline & Leverage & 148,475 & 1341,276 &, 012 & 1 & 912 \\
\hline & GuaranteeStatus $=0$ & $-420,492$ & 3324,790 &, 016 & 1 & ,899 \\
\hline & GuaranteeStatus $=1$ & $0^{c}$ & . & . & 0 & . \\
\hline & GuaranteeStatus $=0$ & $-213,154$ & 6206,676 & ,001 & 1 & ,973 \\
\hline & GuaranteeStatus $=1$ & $0^{c}$ & . & . & 0 & . \\
\hline \multirow[t]{8}{*}{ idAA-(sy) } & Intercept & $-8812,614$ & 84789,626 &, 011 & 1 & 917 \\
\hline & CompanySize & 343,030 & 13996,180 &, 001 & 1 & 980 \\
\hline & Profitability & 50727,049 & 4228043,410 &, 000 & 1 & 990 \\
\hline & Leverage & $-505,614$ & 67310,001 &, 000 & 1 & ,994 \\
\hline & GuaranteeStatus $=0$ & 1529,221 & 317198,535 &, 000 & 1 & 996 \\
\hline & GuaranteeStatus $=1$ & $0^{\mathrm{c}}$ & . & . & 0 & · \\
\hline & GuaranteeStatus $=0$ & 2387,467 & 121006,310 &, 000 & 1 & ,984 \\
\hline & GuaranteeStatus $=1$ & $0^{\mathrm{c}}$ & . & . & 0 & . \\
\hline \multirow[t]{8}{*}{ idAAA(sy) } & Intercept & $-6971,567$ & 21760,346 &, 103 & 1 & ,749 \\
\hline & CompanySize & 308,881 & 1072,502 &, 083 & 1 & ,773 \\
\hline & Profitability & 24961,923 &, 000 & . & 1 & . \\
\hline & Leverage & 679,863 & 2779,429 &, 060 & 1 & ,807 \\
\hline & GuaranteeStatus $=0$ & 52,708 & 3527,766 &, 000 & 1 & 988 \\
\hline & GuaranteeStatus $=1$ & $0^{c}$ & - & . & 0 & . \\
\hline & GuaranteeStatus $=0$ & $-438,306$ & 4939,217 &, 008 & 1 & ,929 \\
\hline & GuaranteeStatus $=1$ & $0^{c}$ & . & . & 0 & . \\
\hline
\end{tabular}

${ }^{a}$ with reference category is $\mathrm{BBB}$ 
The partially analysis by using Wald test shows that the Sukuk rating potentially obtains AAA compared to $\mathrm{BBB}$ if it correlates positively to firm size, level of profitability, level of leverage, guarantee status, and Sukuk Ijarah. The AA- compared to BBB ranking is obtained if the Sukuk rating has a positive correlation with firm size, level of probability, guarantee status and Sukuk Ijarah, and has a negative correlation with level of leverage. Moreover, the A+ compared to BBB ranking is resulted from a positive correlation of Sukuk rating with firm size and level of leverage. Furthermore, the A compared to BBB ranking is achieved when all variables positively correlate to Sukuk rating except level of leverage. The last, the A-compared to $\mathrm{BBB}$ is reached if all variables have negative correlation with Sukuk rating except Sukuk Ijarah.

\section{Fitting Information Model Test}

The Fitting Information Model is to test general fit of the model. The test is conducted by comparing the value of $-2 \log$ likehood in the intercept only to $-2 \log$ likehood in the final. If the first $-2 \log$ likehood is higher than the last $-2 \log$ likehood, the model is considered as good. Besides, the model is said significant or fits the data if $\mathrm{p}$-value $<0.05$. The result of fitting model test showed that the chi square value was 121.958 and was significant with $\mathrm{p}=0.000$.

Table 3. Result of Fitting Information Model Test

\begin{tabular}{lcccc}
\hline Model & $\begin{array}{c}\text { Model Fitting } \\
\text { Criteria }\end{array}$ & \multicolumn{3}{c}{ Likelihood Ratio Test } \\
\hline & -2 Log Likelihood & Chi Square & df & Sig \\
\hline $\begin{array}{l}\text { Intercept } \\
\text { only }\end{array}$ & 121,959 & & & \\
Final & 0,001 & 121,958 & 20 & 0,000 \\
\hline
\end{tabular}




\section{Goodness of Fit Test}

The Goodness of Fit is employed to examine the parameter of model fit, which means that the empirical data does not have differences between the model and the data so that the model is fit with p-value $>0.05$ or $5 \%$. The result of chi square analysis indicated that p-value is higher than 0.05 , therefore, it can be concluded that the model used in this study could accurately predict the observation value.

Table 4. Result of Goodness of Fit Test

\begin{tabular}{lccc}
\hline & Chi Square & df & Sig. \\
\hline Pearson &, 001 & 68 & 1,000 \\
Deviance &, 001 & 68 & 1,000 \\
\hline
\end{tabular}

\section{Pseudo R-Square Test}

This test functions to examine the $\mathrm{R}^{2}$ in multiple regression to check if the independent variables can explain the dependent variable in the model. In the Multinomial Logistic Regression by using Cox and Snell, the value which is closer to 1 shows that the independent variables are able to explain the dependent variable. Based on the result of Cox and Snell which was $88.7 \%$, it was found that the variation of independent variables, i.e. firm size, leverage, guarantee status and Types of Sukuk, can explain the Sukuk rating as the dependent variable. While the rest (11.3\%) were explained by other variables.

Table 5. Result of Pseudo R-Square

\begin{tabular}{lc}
\hline Cox and Snell &, 887 \\
Negelkerke & 1,000 \\
McFadden & 1,000 \\
\hline
\end{tabular}




\section{Likehood Ratio Test}

Likehood Ratio Test describes the contribution of independent variables to the model, which has p-value $<0.05$. According to Borhan and Ahmad (2018), the Likehood Ratio Test becomes a basic of determining the final conclusion on the effect of independent variables to the model. In a similar direction, Arundina (2009) mentions that the Likehood Ratio Test is considered as an accurate significant test to define the effect of each independent variable to the model of a research. The result of Likehood Ratio Test revealed that the contribution of independent variables to the model of this study only provided by Profitability and Guarantee status with significant value or $\mathrm{p}$-value $<0.05$.

Table 6. Likehood Ratio Test

\begin{tabular}{lcrrr}
\hline \multicolumn{1}{c}{ Effect } & Model fitting criteria & \multicolumn{3}{c}{ Likelihood ratio test } \\
\hline & $-2 \log$ likelihood of reduced \\
model & Chi - Square & df & \multicolumn{1}{c}{ Sig, } \\
\hline Intercept &, $001^{\mathrm{a}}$ &, 002 & 4 & 1,000 \\
CompanySize &, $002^{\mathrm{b}}$ &, 001 & 4 & 1,000 \\
Profitability & $12,220^{\mathrm{b}}$ & 12,219 & 4 &, 016 \\
Leverage &, $003^{\mathrm{c}}$ &, 002 & 4 & 1,000 \\
GuaranteeStatus & $25,936^{\mathrm{d}}$ & 25,934 & 4 &, 000 \\
SukukStructure &, $013^{\mathrm{b}}$ &, 012 & 4 & 1,000 \\
\hline
\end{tabular}

Table 7. The Result of Multinomial Model Classification

\begin{tabular}{lccccccc}
\hline \multirow{2}{*}{ Observed } & \multicolumn{7}{c}{ Predicted } \\
\cline { 2 - 8 } & idAAA(sy) & $\begin{array}{c}\text { idAA- } \\
(\text { sy) }\end{array}$ & idA+(sy) & idA(sy) & $\begin{array}{c}\text { idA- } \\
(\text { sy })\end{array}$ & $\begin{array}{c}\text { idBBB } \\
(\text { sy })\end{array}$ & $\begin{array}{c}\text { Percent } \\
\text { correct }\end{array}$ \\
\hline idAAA(sy) & 30 & 0 & 0 & 0 & 0 & 0 & $100 \%$ \\
idAA-(sy) & 0 & 1 & 0 & 0 & 0 & 0 & $100 \%$ \\
idA+(sy) & 0 & 0 & 8 & 0 & 0 & 0 & $100 \%$ \\
idA(sy) & 0 & 0 & 0 & 5 & 0 & 0 & $100 \%$ \\
idA-(sy) & 0 & 0 & 0 & 0 & 6 & 0 & $100 \%$ \\
idBBB(sy) & 0 & 0 & 0 & 0 & 0 & 6 & $100 \%$ \\
Overall & $53,8 \%$ & $1,8 \%$ & $14,3 \%$ & $8,9 \%$ & $10,7 \%$ & $10,7 \%$ & $100 \%$ \\
Percentage & & & & & & & \\
\hline
\end{tabular}


The above table shows prediction result of Multinomial Logistic coefficient in the previous one. The classification model analysis indicates that the $100 \%$ valid cases were classified into the first ranking class.

\section{Discussing the Effects}

The hypothesis of this study is firm size has a positive and significant effect on the Sukuk rating. However, the result of data analysis indicated that the variable of firm size did not positively correlate to the Sukuk rating since the significant value or p-value $>0.05$, which meant the hypothesis was rejected. In other words, the firm size did not have any effect toward the Sukuk rating. It is a common perception that the bigger the company is, the higher its Sukuk rating would be. It is due to the fact that a big company usually has a strong position in an industry, which is different with a developing company that should experience a competitive market. However, the finding of study implies that the size of a company could not be an indicator of the Sukuk rating issued by that company.

The reason of the firm size which does not positively correlate to the Sukuk rating is the investors' perspective that do not consider the size of a company as the benchmark of its performance that will influence the Sukuk rating. Moreover, the risk factor and bankruptcy become primary consideration for the investors to not to trust the firm size as a parameter of Sukuk rating. This bankruptcy risk occurs because most of companies enlarge their investments by owing as financial resources. In terms of firm size and Sukuk rating, the finding of this study confirms the result revealed by Borhan and Ahmad (2018) and Hardianto (2010).

The result of data analysis showed that the variable of Profitability which was measured by using Return on Asset (ROA) had a significant effect to the Sukuk rating, with p-value 0.016 . profitability refers to the ability of a company in obtaining its profit. The more a company obtains 
profit, it must fulfill its bond. The higher the Sukuk rating is, the lower the risk of bankruptcy experienced by a company would be (Widowati, 2013). This finding is in consistent with the result of a study conducted by Borhan and Ahmad (2018, Widowati (2013) and Melani (2013) stating that the profitability which is measured by using ROA significantly effects the Sukuk rating. In the other hand, this finding is not in line with Arundina's (2009) study which concluded that the level of profitability does not positively correlate with the Sukuk rating.

The result of hypothesis testing indicated that the significant value of leverage was higher than $\mathrm{p}$-value, which meant this variable that was measured by Debt to Equity Ratio (DER) did not significantly effect the Sukuk rating. The high value of debt equity ratio indicates that the company has a high amount of debt, so that it will be potentially resulted in the failure of paying its bond. The finding of this study also implies that the Sukuk rating does not show the modal used to cover the company's bond that is going to increase default risk. It has also revealed that although a company has a huge amount of debt, the level of its Sukuk rating is not automatically low. According to Melani and Kananlua (2013), this is because the DER depends on the types of industry and the ways to run business in a company.

The result of this study confirms a previous research conducted by Hamida (2017) and Melani and Kananlua (2013) which conclude that the variable of leverage does not form prediction model of Sukuk rating. Melani and Kananlua (2013) further adds that a company with low level of debt to equity ratio is better than the one having the high level of it, and vice versa.

In terms of Guarantee status, the result of this study showed it had a significant effect to the Sukuk rating, since the significant value was lower than p-value. By establishing a guarantee status, a company can minimize 
the risk of payment failure to the investors. Furthermore, the company can guarantee its assets and property in publishing Sukuk. The previous studies certainly show that the guaranteed Sukuk and Bond by using high value of assets will provide the investors with a comfortable investment. In other words, if the company's assets are used to guarantee its Sukuk, the Sukuk rating will be in a save position. This finding of this study is in consistent with the results of researches conducted by Borhan and Ahmad (2018) and Hasan and Dana (2018) that mention the effect of guarantee status of the Sukuk toward the Sukuk rating. Hasan and Dana (2018) then add that Sukuk which are issued with a high value of guarantee status will give security for the investors.

The last, types of Sukuk was the independent variable which did not have any effect to the Sukuk rating in which its significant value was greater than p-value. The types of Sukuk consisting of Mudharaba and Ijarah are not taken as consideration for the investors in investing Sukuk. In Indonesia, the working performance of a company does not merely depend on certain types of Sukuk. The issuers of Sukuk usually establish a certain type according to their modal and assets which are guaranteed, as a result, it is not used as the basic criteria of working performance assessment. This finding agrees with what has been found by Borhan and Ahmad (2018), who state that the types of Sukuk does not take effect the Sukuk rating issued by a company.

\section{Conclusion}

The present study attempts to examine the effect of determinant variables consisting of financial and non-financial factors on the Sukuk rating. While the financial variables are firm size, level of profitability and leverage, the non-financial variables consist of guarantee status and types of Sukuk. 
Among the three financial variables, there is only the variable of profitability that significantly contributes to the Sukuk rating. This should be because the level of profitability accurately measures the company's ability in earning profits based on the amount of assets. The higher the profits obtained, the lower the risk of bankruptcy would be. Moreover, in terms of non-financial variables, there is the variable of guarantee status which positively correlates with the Sukuk rating. It is potentially due to the Sukuk or Bond that is guaranteed with a high value of assets makes the investors secure in investing their modals.

Based on the finding of the present study, it is suggested that for the companies that publish Sukuk, they should consider the existence of financial and non-financial variables to ensure their Sukuk rating in Use the "Insert Citation" button to add citations to this document.

Furthermore, for the future researchers, it is strongly recommended to employ a longer observation period to obtain more enormous data. Besides, the other determinant variables such as working performance and other related variables should be taken into account in order to examine more factors that takes effect the Sukuk rating. 


\section{References}

Arundina, T., Azmi Omar, M., \& Kartiwi, M. (2015). The predictive accuracy of Sukuk ratings; Multinomial Logistic and Neural Network inferences. Pacific Basin Finance Journal, 34, 273-292. https://doi. org/10.1016/j.pacfin.2015.03.002

Arundina, T., \& Omar, D. M. . (2009). Faktor Penentu Peringkat Sukuk. Buletin Ekonomi, Moneter Dan Perbankan, 105-123.

Azmat, S., Skully, M., \& Brown, K. (2017). The (little) difference that makes all the difference between Islamic and conventional bonds. Pacific Basin Finance Journal, 42(July 2015), 46-59. https://doi. org/10.1016/j.pacfin.2015.12.010

Borhan, N. A., \& Ahmad, N. (2018). Identifying the determinants of Malaysian corporate Sukuk rating. International Journal of Islamic and Middle Eastern Finance and Management, IMEFM-02-2017-0045. https://doi.org/10.1108/IMEFM-02-2017-0045

Elhaj, M. A. A., Muhamed, N. A., \& Ramli, N. M. (2015). The Influence of Corporate Governance, Financial Ratios, and Sukuk Structure on Sukuk Rating. Procedia Economics and Finance, 31(McMillen 2007), 62-74. https://doi.org/10.1016/S2212-5671(15)01132-6

Grassa, R. (2017). Corporate choice between conventional bond and Sukuk issuance evidence from GCC countries. Research in International Business and Finance, (February 2016), 1-13. https:// doi.org/10.1016/j.ribaf.2017.07.179

Hasan, D. A., \& Dana, I. M. (2018). Pengaruh Profitabilitas, Likuiditas, Maturity dan Jaminan Terhadap Peringkat Obligasi Tertinggi Pada Sektor Keuangan Di Bursa Efek Indonesia. E-Jurnal Manajemen Unud, 7(2), 643-673.

Hovakimian, A., Opler, T., \& Titman, S. (2001). The Debt-Equity Choice. The Journal of Financial and Quantitative Analysis, 36(1), 1-24. 
Kumar, K., \& Bhattacharya, S. (2006). Artificial neural network vs linear discriminant analysis in credit ratings forecast. Review of Accounting and Finance, Vol. 5 No. https://doi.org/10.1108/14757700610686426

Ma'arij, A., Zulbahridar, \& Azhar, A. (2014). Analisis Faktor Akuntansi dan Non Akuntansi Yang Mempengaruhi Prediksi Peringkat Obligasi Pada Perusahaan Non Keuangan Yang Terdaftar Di BEI dan Diperingkat Oleh PEFINDO Periode 2009-2013. Jom FEKON, 1(2), 1-13.

Martinus, \& Suryaningsih, R. (2014). Pengaruh Ukuran Perusahaan, Debt to Equity Ratio, Return On Equity, Produktivitas dan Current Ratio Terhadap Peringkat Obligasi (Studi Empiris Pada Perusahaan Keuangan Yang Diperingkat Oleh PT PEFINDO Periode 2012-2014 dan Terdaftar di BEI Periode 2011-20. Ultima Accounting, 6(2), 5676.

Mohamed, H. H., Masih, M., \& Bacha, O. I. (2015). Why do issuers issue Sukuk or conventional bond? Evidence from Malaysian listed firms using partial adjustment models. Pacific Basin Finance Journal, 34, 233-252. https://doi.org/10.1016/j.pacfin.2015.02.004

Nagano, M. (2016). Who issues Sukuk and when?: An analysis of the determinants of Islamic bond issuance. Review of Financial Economics, 31, 45-55. https://doi.org/10.1016/j.rfe.2016.05.002

Nagano, M. (2017). Sukuk issuance and information asymmetry: Why do firms issue sukuk? Pacific Basin Finance Journal, 42, 142-157. https:// doi.org/10.1016/j.pacfin.2016.12.005 
Vol. 4 No. 1, January - April 2019 


\section{Shirkah Author Guidelines}

Shirkab currently offers two routes to submit manuscripts. We highly recommend to submit the articles which are made using OJS (Open Journal System). Feel free register as author soon through visiting http://shirkah. or.id/index.php/home/user/register. The authors may directly send their manuscripts, along with their resume, to shirkahiainsurakarta@gmail. com. Please prepare your manuscripts, using following guidelines:

1. Manuscript must be written in English. Submitted articles should not have been published or be under review for publication with another journal.

2. Manuscript's length is about $15-20$ pages, typed in one-half spaced on A4-paper size.

3. Manuscript must include an $150-200$ word abstract and keywords.

4. Manuscript must be arranged as follows: Title, Name of Author, E-mail address, Abstract, Keywords, Introduction (including method if any), Discussion, Conclusion, References.

5. Manuscript's titles not more than ten words.

6. Manuscript must be submitted in Microsoft Word or RTF.

7. Arabic words should be transliterated according to the style of International Journal of Middle Eastern Studies.

8. Manuscript references are preferably derived from the up-to-date references.

9. The author's resume should be submitted separately, consisting of at least full name, institutional address, phone number, areas of studies, and recent publications (if any).

10. Shirkab use APA Style 6th edition (2010) as reference format writing. We suggest the use of a reference manager software such as Mendeley, Zotero, and Endnote at templating the citation style. APA Style to be used is as follows: 


\section{Book with single author}

Swann, G. M. Peter. (2014). The Economics of Innovation an Introduction. Cheltenhum \& Northampton: Edward Elgar.

in-text citation: (Swann, 2014)

\section{Articles in reference books}

Alatas, S. F. (2006). Islam and the Science of Economics in Abu Rabi', I.M. The Blackwell Companion to Contemporary Islamic Thought. USA: Willey-Blackwell (pp. 587-606).

in text citation: (Alatas, 2006)

\section{E-Book}

Hackett, Rosalind (2007). "Religous Dimentions of War and Peace: Introduction." Dalam Gerrie ter Haar dan Yoshio Tsuruoka (Ed.), Religion and Society: An Agenda for the 21st Century (h. 3-6). Retrieved from http:// brill.nl.

in text citation: (Hackett, 2006)

\section{Master's thesis, from a commercial database}

McNieI, D. S. (2006). Meaning through narrative: A personal narrative discussing growing up with an alcoholic mother (Master's thesis). Available from ProQuest Dissertations and Theses database. (UMI No. 1434728)

in text citation: (Mc Niel, 2006)

\section{Doctoral dissertation, from an institutional database}

Adams, R. J. (1973). Building a foundation for evaluation of instruction in higher education and continuing education (Doctoral dissertation). Retrieved from http://www.ohiolink.edu/etd/

in text citation: (Adams, 1973) 


\section{Doctoral dissertation, from the web}

Bruckman, A. (1997). MOOSE Crossing: Construction, community, and learning in a networked virtual world for kids (Doctoral dissertation, Massachusetts Institute of Technology). Retrieved from http:/www-static. cc.gatech.edu/--asb/thesis/

in text citation: (Bruckman, 1997)

\section{Journal article with No DOI}

Bourkhis, K., and Nabi, M. S. (2013). Islamic and conventional banks' soundness during the 2007-2008 financial crisis. Journal Metrics, 22(2), 68-77.

in-text citation: (Bourkhis \& Nabi, 2013).

\section{Journal article with DOI}

Ichwan, M. (2012). The Local Politics Of Orthodoxy: The Majelis Ulama Indonesia in the Post-New Order Banten. Journal Of Indonesian Islam, 6(1), 166-194. doi:http://dx.doi.org/10.15642/JIIS.2012.6.1.166-194

In text citation : (Ichwan, 2012)

\section{Abstract as citation}

Hasan, N. (2012). Islamist Party, Electoral Politics And Da'wah Mobilization Among Youth : The Prosperous Justice Party (PKS) in Indonesia. Journal of Indonesian Islam, 6(1), 17-47. Abstract from http://jiis.uinsby. ac.id/index.php/jiis/article/view/97

in text citation : (Hasan, 2012)

\section{Mass media article}

Sahal, Akhmad (2014, March 2). Kiai Sahal dan Realisme Fikih.Tempo Magazine, p. 120.

in text citation : (Sahal, 2014) 


\section{Research report}

Fisher, B. S., Cullen, F. T., \& Turner, M. G. (2000). The Sexual Victimization of College Women. Research Report.

in text citation : (Fisher, Cullen, Turner, 2000)

\section{Monograph}

Routray, Bibhu Prasad (2013), National Security Decision-Making in India (RSIS Monograph No. 27). Singapura: Rajaratnam School of International Studies.

in text citation : (Routray, 2013)

\section{Proceeding article}

Sudibyakto, Hizbaron, D.R., \& Jati, R (Ed.) (2009), Proceeding International Seminar Disaster Theory, Research and Policy. International seminar held by Sekolah Pascasarjana, Universitas Gajahmada, Yogyakarta, 8-9 Desember 2009.

in text citation : (sudibyakto and Jati, 2009)

\section{Paper conference/seminar/symposium}

Janutama, Herman Sinung (2011). "Kraton dan Hubungan Antar Agama." Paper presented in Seminar Kraton dan Panatagama held by Center for the Study of Islam and Social Transformation (CISForm), Yogyakarta, 17 November.

in text citation :(Janutama, 2011)

\section{Online article in web}

Shiva, (2006, February). Bioethics: A Third World Issue. Native-web. Diperoleh dari http://www.nativeweb.org/ pages/legal/shiva.html

in text citation : (Shiva, 2006) 


\section{Online research report}

Kessy, S. S. A., \& Urio, F M. (2006). The contribution of microfinance institutions to poverty reduction in Tanzania (Research Report No. 06.3). Retrieved from Research on Poverty Alleviation website: http://www.repoa.or.tz/documents_storage/Publications/Reports/06.3_Kessy_and_ Urio.pcif

in text citation : (kessy and urion, 2006)

\section{Holy book}

Qur an, $2(25)$

In text citation : (Q. al-Baqarah 2:25).

\section{Encyclopaedia}

Graycar, Adam (1992). Social Welfare Policy. Dalam Mary Hawkesworth dan Maurice Kogan (Ed.), Encyclopedia of Government and Politics (Vol. 1). London: Routledge.

in text citation : (Graycar, 1992)

\section{Interview}

Sultan Hamengkubuwono X (interview, 2011, April 19)

in text citation: (Hamengkubuwono, 2011)

\section{Documentary film}

Steijlen, Fridus (2008). A Day in the Life of Indonesia [documentary film, 58 minutes]. Leiden: KITLV Press.

in text citation : (Steijlen, 2008) 
Vol. 4 No. 1, January - April 2019 